\title{
A decade of mangrove conservation achievements and challenges in Vietnam
}

\author{
Pham Thu Thuy ${ }^{1}$ and Nguyen Van Dien²
}

\section{Key messages}

- The last decade has seen significant and marked improvements in the legal framework on mangrove protection, increased funding and involvement of non-state actors in mangrove protection and development, lower rates of mangrove forest loss and larger areas of planted mangroves in Vietnam.

- Despite these remarkable achievements, challenges remain for mangrove conservation, particularly when major drivers of mangrove deforestation and degradation have yet to be properly addressed as they are closely linked to national economic development priorities.

- Weak law enforcement, overreliance on inadequate central budget financing for mangrove protection, and inequitable distribution of benefits and rights relating to mangrove resources further challenge effective, efficient and equitable mangrove management.

- The government still affords more attention to planting new mangroves than providing strong incentives for conserving existing mangrove forests.

- Future mangrove protection and development in Vietnam requires stronger political will from the government to find a balance between economic development and mangrove conservation priorities, as well as participatory decisionmaking processes where the private sector and local communities are provided with better incentives to engage in mangrove protection.

\section{Introduction}

Mangroves provide important ecosystem services for the Vietnamese people. However, increasing pressure from economic development, rapid land-use change and climate change are threatening their sustainability (McNally et al. 2011). Annual mangrove loss in Vietnam was $0.25 \%$ during 2000-2012 (Richards and Friess 2016). In Kien Giang province, which has large expanses of mangrove forest, mangroves were lost at a rate of $-2.7 \% \mathrm{yr}^{-1}$ between 1989-1992 and -2.1\% yr ${ }^{-1}$ between 2003-2006 (Nguyen et al. 2013). In Ca Mau province, net change in mangrove area was $-0.34 \%$ annually between 2004-2009, mainly due to mangrove loss (Hauser et al. 2017). Deforestation rates have been significantly higher in natural mangrove forests than in mangrove plantations (Van et al. 2015). To address these losses, the Government of Vietnam has developed and implemented many mangrove protection policies and called for international support in restoring, replanting and protecting its mangrove areas. However, not all these policies and international projects have achieved their expected outcomes, either in expanding mangrove area or protecting existing mangroves (Hai et al. 2020). As mangrove protection and conservation efforts have had mixed results, their achievements and challenges can offer useful lessons for enhancing the effectiveness of future mangrove conservation policies. Based on a policy review, a review of existing scientific and government literature, donor opinions, international organization reports and the authors' own research and experiences in mangrove conservation and development over the last 10 years, this infobrief aims to discuss the achievements and challenges of past mangrove conservation schemes, and proposes recommendations for future programs and projects on sustainable coastal forest management.

\section{Achievements in mangrove conservation in Vietnam}

The last decade has witnessed important achievements in mangrove conservation in Vietnam. 
First, mangrove protection has received growing political attention in recent years. There has been a dramatic increase in the number of policies incentivizing and regulating mangrove conservation and highlighting the importance of maintaining and extending mangrove forest areas. This not only shows strong political commitment, but also a solid legal foundation to enable mangrove forest protection (see Table 1)

\section{Table 1. Key mangrove conservation policies}

\begin{tabular}{|c|c|c|}
\hline Year & Policy & Details \\
\hline 2007 & $\begin{array}{l}\text { Vietnam Forestry } \\
\text { Development Strategy } \\
\text { 2006-2020 issued } \\
\text { through Decision No. } \\
\text { 18/2007/QD-TTg dated } \\
\text { 05/Feb/2007 }\end{array}$ & $\begin{array}{l}\text { The strategy focuses on the development of mangrove protection, restoration and } \\
\text { development projects in coastal areas in the North, North Central, Central Coast and Mekong } \\
\text { River Delta regions; consolidation and development of sand and wave-buffering forest } \\
\text { systems in the Central Coast regions; development of } 0.18 \text { million ha of protection forests for } \\
\text { wave buffering and preventing saltwater intrusion; and development of } 0.15 \text { million ha of } \\
\text { forests for shielding from winds and wind-blown sand. }\end{array}$ \\
\hline 2013 & $\begin{array}{l}\text { National Forestry } \\
\text { Sector Restructuring } \\
\text { Program issued } \\
\text { through Decision No } \\
1565 / \text { QD-BNN-TCLN } \\
\text { dated } 08 / \text { July/2013 }\end{array}$ & $\begin{array}{l}\text { The program aims to establish } 5.842 \text { million ha of protection forest, including } 0.18 \text { million } \\
\text { ha for wave buffering and preventing saltwater intrusion, and } 0.15 \text { million ha for shielding } \\
\text { from winds and wind-blown sand. It also aims to build and strengthen a system of } \\
\text { watershed protection forests and coastal protection forests for wave and sand buffering } \\
\text { and coastal erosion control, and develop mangrove ecosystems in the Northeast, North } \\
\text { Central Coast; South Central Coast and Mekong River Delta regions. }\end{array}$ \\
\hline 2015 & $\begin{array}{l}\text { Decision No. 120/ } \\
\text { QĐ-TTg } 2015 \text { on } \\
\text { development of } \\
\text { coastal forests to cope } \\
\text { with climate change } \\
\text { during the 2015-2020 } \\
\text { period }\end{array}$ & $\begin{array}{l}\text { This decision promotes the functions of coastal forests in response to climate change, } \\
\text { protecting against sea-level rise, mitigating natural disasters, protecting sea dikes } \\
\text { and infrastructure, conserving biodiversity, enhancing CO2 absorption, and reducing } \\
\text { greenhouse gas emissions, thereby contributing to socio-economic development and } \\
\text { strengthening national defense and security. Specific tasks include: protecting existing } \\
\text { coastal forest areas; restoring 9,602 ha of degraded forests (adjusted to 6,670 ha through } \\
\text { Decision 770/QD-TTg); and planting } 46,058 \text { ha of new forests, including } 29,500 \text { ha of } \\
\text { mangroves, 7,508 ha of wind- and sand-buffering protection forests and 9,050 ha of coastal } \\
\text { production forests (adjusted to 14,930 ha through Decision 770/QD-TTg). }\end{array}$ \\
\hline \multirow[t]{2}{*}{2016} & $\begin{array}{l}\text { Decree No. 119/2016/ } \\
\text { ND-CP on Sustainable } \\
\text { Management, } \\
\text { Protection and } \\
\text { Development of } \\
\text { Coastal Forests }\end{array}$ & $\begin{array}{l}\text { Use of the central budget to: support contracted mangrove protection at } 1.5 \text { times the } \\
\text { previous average rate and zonation for natural regeneration - VND } 4 \text { million/ha for } 5 \text { years } \\
\text { (average VND 800,000/ha/year); and prepare contracts of VND 50,000/ha for forest protection } \\
\text { and zonation to promote natural regeneration. The central budget is used for investing } \\
\text { in coastal forest development according to approved projects, including: assessment and } \\
\text { planning of coastal forest protection and development; afforestation; zoned regeneration } \\
\text { with additional afforestation; construction of anti-landslide, sedimentation and ground } \\
\text { formation works to restore and develop coastal forests; construction work and procurement } \\
\text { of equipment for coastal forest protection and development; and management, inspection } \\
\text { and approval of projects on coastal forest protection and development. }\end{array}$ \\
\hline & & $\begin{array}{l}\text { Local government budgets are used for: generating forestry statistics: forest inventories } \\
\text { and monitoring natural changes in forests; allocation and lease of coastal forests; coastal } \\
\text { protection and special-use forest management board activities; education and awareness } \\
\text { raising; forestry extensions; capacity building; research and application of scientific and } \\
\text { technological advances in coastal forest protection and development; investment; and } \\
\text { financial support additional to support and investment from the central budget. }\end{array}$ \\
\hline 2017 & $\begin{array}{l}\text { National REDD+ } \\
\text { Strategy } 2017\end{array}$ & State provision of support to plant 30,000 ha of coastal forests from 2017-2020. \\
\hline 2017 & Forestry Law 2017 & $\begin{array}{l}\text { The law regulates: government approval of coastal forest utilization, with the National } \\
\text { Assembly having authority over areas of } 500 \text { ha or more, the Prime Minister over areas of } \\
20-500 \text { ha, and Provincial People's Councils over areas of less than } 20 \text { ha; establishment of } \\
\text { forest belts appropriate to natural conditions in each region; afforestation using plants with } \\
\text { firmly attaching deep root systems, prioritizing indigenous species and resilient species for } \\
\text { planting in harsh conditions; and additional planting in places yet to meet the criteria to be } \\
\text { considered forests. The law requires a payment scheme to be developed and implemented } \\
\text { for mangrove environmental services, such as providing breeding grounds, food, natural } \\
\text { seeds, water sources from forest and elements from forest ecosystems for aquaculture. }\end{array}$ \\
\hline
\end{tabular}


Table 1. Continued

\begin{tabular}{|c|c|c|}
\hline Year & Policy & Details \\
\hline 2020 & $\begin{array}{l}\text { Vietnam's Nationally } \\
\text { Determined } \\
\text { Contribution (NDC) } \\
\text { submitted in } 2020\end{array}$ & $\begin{array}{l}\text { Increase forest cover to } 42 \%-42.5 \% \text {; increase the area of coastal protection forests, } \\
\text { including mangrove plantations; and preserve and sustain forest ecosystems. The NDC } \\
\text { prioritizes: planting coastal forests; restoring protection forests and special-use forests; } \\
\text { raising awareness of and building sustainable management models for mangrove forests } \\
\text { for coastal protection; implementing sustainable forestry development program targets } \\
\text { for the } 2016-2020 \text { period; conserving and enhancing forest carbon stock; protecting, } \\
\text { restoring and planting mangrove and coastal protection forests; and aiming to exceed } \\
2020 \text { plans by over } 30 \% \text {. }\end{array}$ \\
\hline 2021 & $\begin{array}{l}\text { One billion tree } \\
\text { planting program } \\
\text { issued by the Prime } \\
\text { Minister in } 2021\end{array}$ & Vietnam should plant an additional one billion trees, including coastal forests by 2025. \\
\hline 2021 & $\begin{array}{l}\text { Vietnam Forestry } \\
\text { Development Strategy } \\
2021-2030 \text {, with vision } \\
\text { to } 2050\end{array}$ & $\begin{array}{l}\text { The State needs to develop coastal forests and will develop a national program on } \\
\text { protecting and developing coastal forests in response to climate change for the } 2021-2030 \\
\text { period. }\end{array}$ \\
\hline
\end{tabular}

Source: Data compiled by the authors in 2021

Ten years ago, public and media narratives focused mainly on inland and upland forests, but these narratives have changed with increasing emphasis being placed on the importance of mangroves for climate change mitigation and addressing environmental issues such as coastal erosion. Increased political interest has also led to greater investment in mangrove protection. An example of this is the upcoming Decision on Forestry Sectoral Investment stipulating that payments for mangrove forest protection will be higher than those for inland forests.

Second, the rate of mangrove loss has gradually fallen. In 2019, the Ministry of Agriculture and Rural Development (MARD) claimed that thanks to the many mangrove conservation policies in place, the number of cases involving forest protection and development violations in coastal provinces had fallen by $30 \%$ between the 2011 2015 and 2016-2018 periods, and more than 140,566 ha of coastal forests a year had become subject to protection contracts. In addition, there had been no changes in the ways mangroves and coastal forests are utilized (MARD 2019). Strict enforcement of existing policies has played a significant role in reducing mangrove loss, while economic development resulting from changing lifestyles has also been a contributory factor. For example, Pham et al. (2019) found fewer mangrove trees being cleared by local people because they have replaced traditional firewood collection with alternative energy options such as gas and cookstoves. These authors also found urbanization with migration from rural to urban areas reducing pressures on mangrove forests. In addition, international demand for ecofriendly products, such as certified seafoods that meet environmental requirements like mangrove protection, has also made government agencies and local people more aware of the need to protect mangrove forests (Ha et al. 2012).
Third, a more cross-sectoral approach to mangrove protection has emerged, with a shift from traditional and only State funded efforts to stronger involvement from international organizations and the private sector (Hai et al. 2020). Since the 1990s, large areas of mangrove forest have been rehabilitated by international NGOs such as the Red Cross, JICA, Oxfam, etc. Many international and national private sector initiatives have focused on mangrove protection, such as Standard Charter (Standard Chartered Bank 2012), Stadtwerke Münster (Leonard 2018) and Green Happiness (Song Foundation 2018). These private sector initiatives have not only provided additional funding for mangrove protection and development in Vietnam but have also raised public awareness on the need to protect mangroves. Recognizing the importance of non-state actors' contributions to mangrove conservation, the Government of Vietnam has developed national schemes on Payments for Forest Environmental Services (PFES) and Reducing Emissions from Deforestation and Degradation (REDD+) with mangrove-related payments being a prominent feature of such schemes. Consequently, according to MARD (2019), 10,600 ha of new forests have been planted (including 5,966 ha of mangroves); 3,500 ha of forests have been restored or replanted (including 2,317 ha of mangroves); and 1.2 million trees, including mangrove species, have been planted each year. Between 2000-2012, total funding for coastal forest protection and development was VND 5,415 billion (MARD 2019) as shown in Table 2.

\section{Mangrove conservation challenges in Vietnam}

Despite the achievements described in the previous section, numerous factors still pose challenges to sustainable mangrove management and conservation in Vietnam. 
Table 2. Funding sources mobilized for mangrove protection and development in Vietnam.

\begin{tabular}{|c|c|c|c|c|}
\hline \multirow[t]{2}{*}{ Funding sources } & \multirow{2}{*}{$\begin{array}{l}\text { Planned funding } \\
\text { (Decision 120/QD-TTg) }\end{array}$} & \multicolumn{2}{|c|}{ Approved funding (2015-2020) } & \multirow[t]{2}{*}{ Rate \% } \\
\hline & & $\begin{array}{l}\text { No. of } \\
\text { projects }\end{array}$ & $\begin{array}{l}\text { Funding } \\
\text { (VND } \mathrm{x} \text { billion) }\end{array}$ & \\
\hline $\begin{array}{l}\text { Forest protection and development schemes } \\
\text { (Sustainable Forestry Development Program target) }\end{array}$ & $1,951.3$ & 17 & 284 & 14.6 \\
\hline Support Program - Response to Climate Change & 1,593 & 41 & 1,912 & 120.0 \\
\hline $\begin{array}{l}\text { Funding for strengthening, protecting and } \\
\text { upgrading sea dikes }\end{array}$ & 247 & 8 & 17 & 6.7 \\
\hline $\begin{array}{l}\text { Official development assistance (ODA) and foreign } \\
\text { funding }\end{array}$ & $1,397.5$ & 7 & 1,926 & 137.8 \\
\hline $\begin{array}{l}\text { Other funding sources (local budgets, funding from } \\
\text { businesses, organizations, individuals, etc.) }\end{array}$ & 226.2 & 15 & 2,872 & $1,269.5$ \\
\hline Total & 5,415 & 88 & 7,010 & 129.5 \\
\hline
\end{tabular}

Source: MARD (2019)

First, while efforts to secure sustainable financing for mangrove protection and develop legal frameworks for incentivizing local people to protect forests have increased, major drivers of mangrove deforestation and degradation have yet to be addressed. These drivers, including infrastructure development, expansion of aquaculture production and expansion of coastal economic development zones and port facilities, are rooted in national economic development goals to boost the maritime economy and safeguard national security (Binh et al. 2008, Nguyen et al. 2013, Son et al. 2015, Pham and Kunihiko 2016). While government solutions for protecting mangroves rest on the underlying narrative that local people are the main driver of mangrove loss, and therefore solutions need to be developed to support local communities and local peoples, the major drivers listed above are overlooked. As there are no coherent cross-sectoral policies or coordination, development in one sector comes at the expense of the forestry sector and its mangroves (MARD 2019, Neil et al. 2011). Moreover, the costs of planting and protecting mangroves are high, while Central Government support for forest and coastal forest protection and development projects is limited (MARD 2019). Unfulfilled or untimely funding allocation has made it impossible to prepare seedlings for mangrove afforestation in a judicious manner. It is becoming increasingly difficult to find areas for mangrove replanting due to land-use change from other sectors.

Second, despite many policies being in place, weak law enforcement, unclear government agency organizational mandates, and insufficient financial and human resources have impeded their implementation (Tran et al. 2021). Pham et al. (2019) found that mangrove forest protection in Vietnam is financed through six funding sources: the state budget; provincial budgets; the national Payments for Forest Environmental Services (PFES) scheme; foreign projects; public-private partnerships; and the private sector. However, forest owners cannot always access these sources due to unclear and complex red tape, the requirement for counterpart funding, and the high initial investment costs necessary for meeting access criteria (Pham et al. 2019). Moreover, climate change adaptation measures mostly focus on hard measures, such as constructing embankments and improving foundations, while soft approaches such as mangrove forest plantation do not receive adequate attention (Government of Vietnam 2020). Differing motivations and weak local government capacity have prevented national policy visions being implemented effectively at the local level (Korbee et al. 2019).

Third, many policies and projects focus on planting new forests but place little emphasis on protecting existing forests (see Table 1). Our review shows the State providing higher payments for local communities to plant new mangroves, while payments to protect existing mangroves are limited. For example, the State provides VND 30,000,000 per hectare to support mangrove planting and pays local people VND 200,000 a day to plant new mangroves. Meanwhile, the annual mangrove forest protection contracts local people sign with government agencies only provide around VND 300,000 per hectare. When mangrove plantation projects take place, inappropriate site and species selection, and limited involvement of local people in mangrove protection and development decision making have led to failures in many projects (Hai et al. 2020).

Fourth, monitoring and evaluation systems are lacking, particularly for monitoring private sector commitments. Statistics and reports on the current status of forest areas and developments, and the outcomes of local coastal afforestation projects remain inadequate, inaccurate and inconsistent (MARD 2019). Even though the private sector has asked the government to approve large areas for forest protection, and foundations are in place to plant and rehabilitate existing mangroves, there is no monitoring or evaluation of how commitments translate to action on the ground. Data on private sector management of mangroves and forest areas is scarce. 
Fifth, elite capture and inequitable benefit-sharing mechanisms also dissuade local people from engaging in mangrove protection conservation schemes. Most mangrove forests are managed by government agencies including state forest management boards, military units, and commune people's committees, whereas only $6 \%$ of mangrove forests in Vietnam are managed by households and local communities. According to MARD (2019), only 29 of Vietnam's 63 provinces (46\%) have mangrove and coastal forests, and most of these are in the Mekong Delta region (MARD 2019). While mangrove forests in northern regions are often scattered, small in area (often less than 2 hectares) and managed by government agencies, mangroves in the south are often much larger (20-30 hectares) and while still managed by government agencies, they are mostly managed by individual households. Although the 2017 Land Law and Forestry Law acknowledges households' rights to access and benefit from forest resources, its implementation is either delayed or not properly enforced, and there are differences between farmers and the private sector as the former's de facto rights to access mangrove timber markets are blocked (Ha et al. 2014). As the poor have limited access to forest resources, they are often excluded from government programs, leaving them uninterested in participating in mangrove protection schemes (Neil et al. 2011).

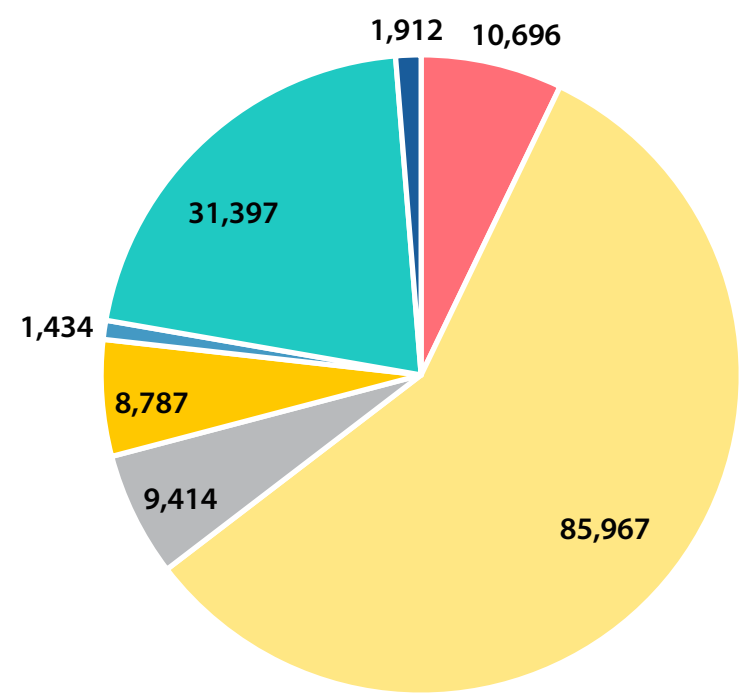

- Special-use forest management boards Protection forest management boards

Economic units, scientific units, training units, forestry enterprises

- Households, local communities

Military units

- Commune people's committees (not yet allocated)

- Other organization

Figure 1. Mangrove managers in Vietnam in 2018 Source: MARD (2019)

\section{Conclusions}

The last decade has seen significant and marked improvements in the legal framework on mangrove protection, increased funding and involvement of non-state actors in mangrove protection and development, lower rates of mangrove forest loss and larger areas of planted mangroves in Vietnam. Despite these remarkable achievements, challenges remain for mangrove conservation, particularly when major drivers of mangrove deforestation and degradation have yet to be properly addressed as they are closely linked to national economic development priorities. Current mangrove protection and development policies view mangrove protection as a technical solution for addressing climate change but overlook the complexities and conflicts of interest between sectors and stakeholders. Weak government and law enforcement, overreliance on inadequate central budget financing for mangrove protection, and inequitable distribution of benefits and rights relating to mangrove resources further challenge effective, efficient and equitable mangrove management. The government still affords more attention to planting new mangroves than providing incentives for conserving existing mangrove forests. Future mangrove protection and development in Vietnam requires stronger political will from the government to find a balance between economic development and mangrove conservation priorities, as well as participatory decision-making processes where the private sector and local communities are provided with better incentives to engage in mangrove protection.

\section{Acknowledgement}

This research is funded by United States Agency for International Development (USAID) through the Sustainable Wetlands Adaptation and Mitigation Program (SWAMP).

\section{References}

Binh CT, Phillips MJ, Demaine H (2018) Integrated shrimpmangrove farming systems in the Mekong delta of Vietnam. Aquaculture Research 28(8): 599-610.

MARD (2019) Overview of present management and effectiveness of policies on mangrove protection and development in Vietnam: Future policy orientations and information gap. MARD, Hanoi, Vietnam.

Powell N, Maria O, Tan SB, Toan VC (2011) Mangrove Restoration and Rehabilitation for Climate Change Adaptation in Vietnam. World Resources Report Case Study. Available at: https:// www.wri.org/our-work/project/world-resources-report/ mangrove-restoration-and-rehabilitation-climate-change. Accessed on 12 July 2021.

Ha TTP, Han VD, Visser L (2014) Impacts of changes in mangrove forest management practices on forest accessibility and livelihood: A case study in mangrove-shrimp farming system in Ca Mau Province, Mekong Delta, Vietnam. Land Use Policy 36: 89-101.

Ha TI, Bush SR, Mol APJ, Dijk HV (2012) Organic coasts? Regulatory challenges of certifying integrated shrimp- 
mangrove production systems in Vietnam. Journal of Rural Studies 28 (4): 631-639.

Hai NT, Dell B, Phuong NT, Harper RJ (2020) Towards a more robust approach for the restoration of mangroves in Vietnam. Annals of Forest Science 77(18).

Hauser LT, Nguyen GV, Nguyen BA, Dade E, Nguyen HM, Nguyen TQT, Le TQ, Vu HL, Tong TAH, Pham HV (2017) Uncovering the spatio-temporal dynamics of land cover change and fragmentation of mangroves in the Ca Mau peninsula, Vietnam using multi-temporal SPOT satellite imagery (2004-2013). Applied Geography 86: 197-207.

Leonard N (2018) Final report on a 7-year reforestation project implemented on Cat Ba Island in Vietnam. AsiaPacific Economic Cooperation.

Korbee D, Quan NH, Hermans L, Long PH (2019) Navigating the bureaucracy: An analysis of implementation feasibility for the Mekong Delta Plan, Vietnam. Journal of Environmental Planning and Management 62(9): 1545-1561.

Government of Vietnam (2020) Updated Nationally Determined Contribution (NDC). The Socialist Republic of Vietnam, Hanoi, Vietnam.

McNally R, McEwin A, Holland T (2011) The Potential for Mangrove Carbon Projects in Vietnam. Netherlands Development Organization, Netherlands.

Nguyen HH, McAlpine C, Pullar D, Johansen K, Duke NC (2013) The relationship of spatial-temporal changes in fringe mangrove extent and adjacent land-use: Case study of Kien Giang coast, Vietnam. Ocean \& Coastal Management 78: 12-22.

Pham TD, Kunihiko Yoshino (2016) Impacts of mangrove management systems on mangrove changes in the Northern Coast of Vietnam. J-Stage 24 (4).
Pham TT, Hoang TL, Nguyen DT, Le HN, Atmadja S (2019) Funding the protection and development of mangrove forests at sub-national level: Lessons from Ben Tre, Tra Vinh and Ca Mau provinces, Vietnam. CIFOR: Bogor, Indonesia.

Richards DR, Friess DA (2016) Rates and drivers of mangrove deforestation in Southeast Asia, 2000-2012. Proc Natl Acad Sci 113: 344-349.

Sống Foundation (2018) Chương trình "Hạnh Phúc Xanh". https://song.org.vn/hanh-phuc-xanh/

Son NT, Chen CF, Chang NB, Chen CR, Chang LY, Thanh BX (2015) Mangrove Mapping and Change Detection in Ca Mau Peninsula, Vietnam, Using Landsat Data and Object-Based Image Analysis. IEEE Journal of Selected Topics in Applied Earth Observations and Remote Sensing 8(2):503-510.

Standard Chartered Bank (2012) Standard Chartered (Vietnam) Acts for Vietnam Green. Accessed on 2 June 2021. https:// www.sc.com/global/av/vn-scb-acts-4-vietnam-green.pdf

Tran VD, Nguyen TKC, Pham TD (2021) Chapter 8-Governance of mangrove ecosystems in Northern Vietnam with consideration of impacts of sea level rise and climate change: A dynamic approach, Natural Resource Governance in Asia. From Collective Action to Resilience Thinking 2021: 99-133

Van TT, Wilson N, Thanh-Tung H, Quisthoudt K, Quang-Minh V, Xuan-Tuan L, Dahdouh-Guebas F, Koedam N (2015) Changes in mangrove vegetation area and character in a war and land use change affected region of Vietnam (Mui Ca Mau) over six decades. Acta Oecologica 63: 71-81.

Vietnam with consideration of impacts of sea level rise and climate change: A dynamic approach. Natural Resource Governance in Asia: 99-133.

The CGIAR Research Program on Forests, Trees and Agroforestry (FTA) is the world's largest research for development program to enhance the role of forests, trees and agroforestry in sustainable development and food security and to address climate change. CIFOR leads FTA in partnership with Bioversity International, CATIE, CIRAD, ICRAF, INBAR and TBI.

FTA's work is supported by the CGIAR Trust Fund: cgiar.org/funders/

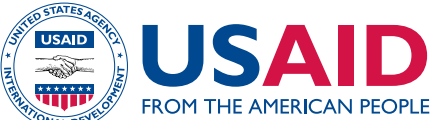

